


\section{Working the Speaking Skill by Using a Web Page in English Classes}

Utilizando una pagina web en la clases de inglés para trabajar la habilidad de hablar

\section{Ilba Yaneth Rodríguez Tamayo}

Universidad Pedagógica y Tecnológica de Colombia

ilba.rodriguez@uptc.edu.co

\section{Yelipsa Barrera Parra}

Servicio Nacional de Aprendizaje, SENA

yely26-94@hotmail.com

\section{Amanda Lizeth Burgos Jimenez}

Colegio la Presentación de Tunja amlibuji@gmail.com

\section{Adriana Lizeth Cuevas Peña}

Universidad Pedagógica y Tecnológica de Colombia adrianalizethcuevaspe@gmail.com

\section{Andrea Nataly Lara Vargas}

Colegio Gimnasio el Bosque, Chiquinquirá, Colombia satela0530@gmail.com

Received: March 11, 2020

Accepted: July 24, 2020

How to cite this article (APA, 7th ed.):

Rodríguez, I. Y., Barrera, Y., Burgos, A. L., Cuevas, A. L., \& Lara, A. N. (2020). Working the speaking skill by using a web page in English classes. ENLETAWA Journal, 13(2), 49-73. 


\section{Abstract}

Information and communication technologies, or ICTs, have gained importance in the globalized world. Meanwhile, they are also a challenge for teachers, who might be reflecting on their teaching practices. The following paper reports on a study developed with sixth graders at a public institution in Tunja, Colombia. The study was implemented during the first semester of 2016, and its goal was to develop speaking skills through workshops organized on a web page. Data was collected through field notes, students' artifacts, recordings, and questionnaires. The results showed that the use of ICTs caught the students' attention, encouraged them to speak English, and increased their vocabulary. Being able to speak and understand more vocabulary could help students use the language in real life situations, as well as reinforce their learning autonomy.

Key words: autonomous learning, English speaking skill, English teaching through ICTs

\section{Resumen}

Este mundo globalizado ha abierto un amplio espacio a las TICS (Tecnologías de la Información y la Comunicación) y ha sido un gran reto para los profesores que quieren reflexionar acerca de la manera de enseñar. Este documento reporta la investigación desarrollada con estudiantes de sexto grado de una institución pública en Tunja, Colombia, la cual fue diseñada e implementada en el primer semestre del 2016 con el objetivo de desarrollar la habilidad de habla, a través de la aplicación de diferentes talleres, organizados apropiadamente en una página web. Los datos para esta investigación cualitativa fueron recopilados a través de notas de campo, trabajos de los estudiantes, grabaciones y cuestionarios y evidenciaron como el uso de TIC contribuye a atraer la atención de los estudiantes, a animarlos a hablar en inglés, así como también a aumentar el vocabulario que se usa en situaciones reales y a fortalecer su autonomía.

Palabras clave: aprendizaje autónomo, Enseñanza del inglés a través de TICS, habilidades de habla en inglés 


\section{Introduction}

Recently, the use of technologies has been a challenge for teachers, who seek to promote meaningful learning experiences for their students. These challenges are caused by many factors, one of which is the fact that students are considered digital natives. It is not a secret that many teachers, who were not taught to use technology, struggle to implement strategies and activities that merge teachers' methodologies with students' ways of learning. San Martín (2009, as cited in Molina \& Mesa, 2018) mentioned that one of main difficulties in incorporating technology in the classroom is the digital gap between students and teachers. At the same time, Espuny, Gisbert, and Coiduras (2010) affirmed that nowadays the goal is to learn by using technology and not to learn how to use it. The previous fact has had a great impact in education and in the learning and teaching processes.

Nevertheless, the reality could be an opportunity for students and teachers to enjoy the use of ICTs, while meeting national and international educational policies and curriculums. For example, the World Forum About Education established an action framework known as "Dakar Action Framework" (UNESCO, 2000, as cited in Hung, 2015). The framework established that research and teaching practices about technology were essential, which spurred changes in teaching practices and the academic community.

In Colombia, Law 1341 of 2009 defined ICT as a set of resources, tools, equipment, system programs, applications, nets, and information transmission. Based on the same law, Article 39 established the Department of Technologies of Information and Communication, which is in charge of implementing the ICT Plan for Education. According to this law, the Department of Technologies of Information and Communication has to promote entrepreneurship in ICTs in educational institutions, start a national system of digital literacy, and help teachers learn ICT use.

Molina and Mesa (2018) mentioned that when the law was first implemented few systems of infrastructure and equipment were available. It was not until the beginning of the $21^{\text {st }}$ century that the Colombian government guaranteed "technology effective appropriation by public institutions which had the equipments" (p. 80). According to Selwyn (2004, as cited in Hung, 2015), aspects like adequate access to ICT resources, equipment use time, connectivity, and technological resources increases, thereby, creating a favorable environment for ICT integration into school curriculums.

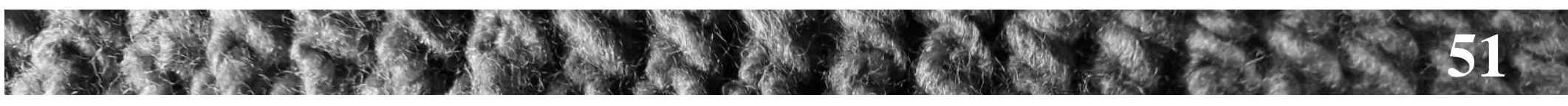


Incorporating technology in the class has been an alternative for teachers to innovate and impact the educational environment. Chacón and Pérez (2011, as cited in Rico, Ramírez, \& Montiel, 2016) expressed that ICTs in English teaching constitute a learning resource and a motivation to practice and use the language in real situations. According to Molina and Mesa (2018), it is not enough to own digital technologies because it is essential to be able to use them appropriately. For teachers, that means being able to develop meaningful classes with ICTs. In addition, the teacher must consider, when using any kind of material in the class, not just the quality but also how it fits with the academic purposes of the school. Menchén (2009, as cited in Molina \& Mesa, 2018) stated society has changed, and teachers have been affected by the evolution. Thereby, teachers' competences have also changed, and they have had to be more creative. The previous idea is supported by Rico et al. (2016), who said that foreign language teachers face the challenges of ICT use in teaching the communicative competence of a language.

Given the interest and progress in ICT use among teachers and educational institutions, we decided to work with technology in the classroom. We designed six workshops with interactive activities that we organized on a web page. The web page was created using Flash, an informatic app that designs multimedia tasks. We implemented the web page with sixth grade students at a public institution in Tunja, Colombia during their English class as a classroom project. The students' ages ranged from 11 to 16 years of age.

The web page was meant to be motivating for students and meaningful in helping them develop their speaking skills. According to Gnambs and Hanfstingl (2016), intrinsic motivation is linked to higher academic engagement and higher grades. However, “... beginning at an early age academic intrinsic motivation starts do decline..." (p. 1691). The authors also stated that "During adolescence school gradually becomes less pivotal in adolescents' cognitive, emotional and social life and, thus, is probably less successful at adequately addressing students' basic needs" (p. 1691). In that sense, motivation was a key factor in developing the activities and catching the students' attention.

In addition to motivation, we observed that the school had a virtual classroom with tablets that were not being used by the students or teachers. Molina and Mesa (2018) developed a study at several public schools in Tunja, and they found that for every seven students there were two tablets on average. The authors also concluded that Languages, Mathematics, and Science classes used the tablets more than other subjects. In our case, the technology was not being used at all, and

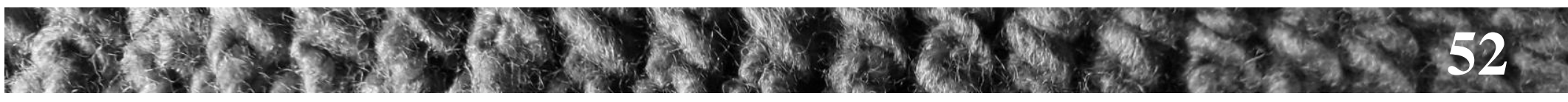


the students were missing out on the opportunity to use a practical and didactic tool that could help them develop their skills and motivation to learn.

Another aspect of this study was the focus on speaking skills. We noticed the students could read and write well, but they had weaknesses in their listening and speaking skills in English. Rico et al. (2016) mentioned that developing the speaking skills is a challenge, and it is necessary to include activities that combine technology and educational resources. Other reasons for weaknesses in the oral skill include a lack of vocabulary, low level of pronunciation, shyness, or embarrassment of being wrong. According to Restrepo (2015), the learning a second language depends largely on vocabulary. The author suggested that "reading is more beneficial for low and intermediate learners" (p. 164). Additionally, Vidal (2011, as cited in Restrepo, 2015) mentioned that listening "was found to be of improvement for vocabulary retention in advanced L2 learners" (p.164). Given the previous statement, the present study used listening activities implemented through a web page to help lower level language learners acquire and retain vocabulary.

Inside the classroom, speaking is least developed skill. Students are used to developing writing and reading exercises, which are commonly focused on grammatical rules and lack language function and context. According to Brown (1994), "Speaking is an interactive process of constructing meaning that involves producing, receiving and processing information” (n.p.). In that sense, form and meaning depend on the context in which it occurs. Context includes the participants, their collective experiences, the physical environment, and the purposes for speaking. It is often spontaneous, open-ended, and evolving.

To conclude, this study sought to improve students' speaking skill through a web page that was full of interactive activities and workshops. The research question was stated as follows: What does the implementation of a web page reveal in the improvement of students' speaking skills?

\section{Theoretical Support}

In order to theoretically support this study, it was necessary to consider theoretical constructs like Information and Communications Technologies, foreign language communicative competence, and autonomy.

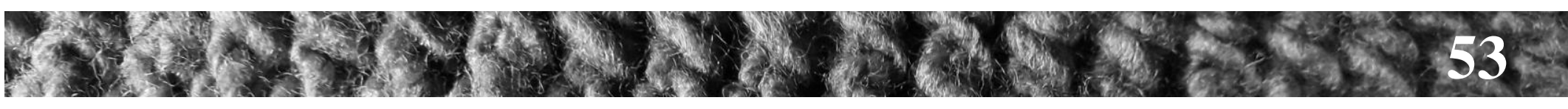




\section{Information and Communications Technologies (ICTs)}

In the teaching-learning process, technology is used to encourage students. It satisfies visual, sensitive, and auditory senses. Information and Communication Technologies (ICTs) are often used as an extended synonym for Information Technology (IT), but it is a specific term that stresses the role of integrating telecommunications.

In terms of technology, students may have the motivation and resources to access the internet from different places and look for the tool to work autonomously. Authors like Zea, Atuesta, López, and González (as cited in Hung, 2015) expressed that the goal of ICTs is not only to provide a huge quantity of information for teachers and students, but to also develop abilities like autonomous learning. Applications, webpages, electronic workbooks, and online programs can provide students with vocabulary, grammar, and pronunciation among other information. Meanwhile, it allows learners to create and produce their own work and learning based on exercises that supplement foreign language instruction. Clearly, ICTs can motivate students and offer a variety of meaningful, interesting, and purposeful resources.

Due to the availability of ICTs and the internet at the school we worked at, we decided to work on a webpage for students to improve their speaking skills as autonomous learners guided by the teacher. According to Christensson (2006), a web page can be defined as "What make up the World Wide Web. These documents are written in HTML: hypertext markup language. It can either be static or dynamic." In this case, webpages can provide plenty of possibilities to promote students' integral learning. Based on Bruce and Levin (1997) inquiry and communication tools, as well as tools for construction are provided by web pages. Thereby, teachers can establish and plan activities that help students discover new ways of learning and applying what they have learnt. The activities implicitly included the use of reading, writing, listening, and especially speaking. The students practiced these skills in motivating ways while learning and having fun.

In addition, Restrepo (2015) expressed that “...the inclusion of new technologies in the L2 class enhances the incidental acquisition of vocabulary and it could help us to improve current reading strategies and tasks in our learning environment" (p. 165). Though the focus for this study was not on improving reading strategies, the inclusion of new technologies could aid in developing speaking skills. 
to be empowered and achieve social transformation. That is the reason why being autonomous requires a consciousness of the self-education process, as well as being involved in a social context where the participants share their knowledge and experiences. By doing so, students can develop different competences through activities molded to the learner's likes and needs.

The self-education process involves the learners' engagement to develop skills like initiative, responsibility, self-government, independent work, and empowerment over their own learning process. Dickinson (1987) mentioned that an autonomous learner can work on accepting his or her own decisions throughout the process without the direct control of the teacher. In this way, the use of technologies as an alternative to practice English allowed students to find more than one tool to learn the language. In fact, one of the main focuses of this study was to promote different ways to learn meaningfully through images, audios, and games. The web page let each student have the opportunity to select the time to practice outside the classroom and the way to learn the language, thereby, fostering autonomous learning. In the following section, we will discuss the research methodology and tools we used to obtain and analyze the data.

\section{Method}

This research study followed the qualitative paradigm. In Heighman and Croker's words (2009), “...qualitative research entails collecting primarily textual data and examining it using interpretive analysis..." (p. 5), which is exactly what this study aimed to do. First, we collected data through instruments like the students' artifacts and questionnaires. After that, we analyzed the data in order to look for answers to the main research question. As mentioned before, we sought to understand what webpages could reveal about improving the speaking skill. Since we were contributing to a potential change in the current syllabus, we framed this study under the action research approach. According to Hopkins (2002), action research gets its origins from the Schools Council's Humanities Curriculum Project (1967-72) with its emphasis on an experimental curriculum and the re-conceptualization of curriculum development. The study also fit features of Burns' (2015) action research. The first aspect deals with how this study could bring positive change and improvement in the participants' social situation. A second feature was that it allowed to generate practical knowledge about the situation. Finally, the study provoked collegiality, collaboration, and involvement of participants, who were actors in the situation (p. 187).

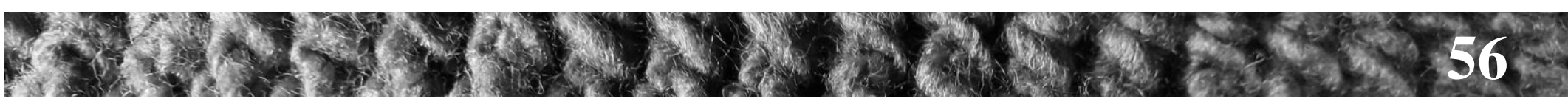


The intervention was done at a public institution in Tunja, Colombia starting with a position of participative observation and ending in a methodologist implementation of a web page to improve the speaking skill. For this study, we picked three data collection instruments and analyzed each one.

\section{Data Collection Instruments}

In order to gather information, we chose three instruments: field notes, teacher and students' artifacts, students' recordings, and questionnaires.

Field notes helped us describe and sequence the events that happened in the classroom. It provided a light on the educative context, such as how students performed in the classroom and how they faced difficult challenges. The field notes that researchers applied were proposed by a Professor of the School of Languages from Universidad Pedagógica y Tecnológica de Colombia. For the field notes, we described the workshop procedure, time, resources, participants, aims, theoretical basis, and evidences. Also, there was a second part where we could reflect and evaluate the activities, such as the achievements and difficulties. Finally, we asked ourselves questions on how to improve future workshops.

Another instrument we used were teacher and students' artifacts. We began by analyzing the school syllabus to understand the specific topics being taught in class for each grade. This document supported the selection of activities and their design. The activities were designed using Flash, and the workshops were available at the web page http://enhancingenglish.com. In addition, we collected students' written reflections and audio recordings.

For this study, the audio recordings were the main tool to collect and analyze data. It is necessary to clarify that the recordings were considered as students' artifacts, and we used the recording to analyze and verify improvements in their speaking skill. We decided to open the possibility for the children to record themselves and upload their audio recording to the web page.

Additionally, we decided to give students a questionnaire to obtain feedback on their perceptions about their own performance in the English class. The gathered information clarified how students implemented the workshop in their learning strategies. Burns (2015) asserted that non-observational and introspective techniques involve seeking views, beliefs, and opinions




about issues under investigation. They also include collecting artifacts from the research site, such as documents (policies, curricula, lesson plans, student work, and test results) providing a track record or paper trail that reflect people's activities. The two main types of nonobservational data collection are interviews and questionnaires, and we chose to implement the latter.

\section{Pedagogical Objective}

With the help of a systems engineer, we designed a web page for students who had a basic level of English, in terms of the speaking skill. The web page offered a variety of activities in which grammatical aspects were implicit. Students had the opportunity to manifest knowledge, feelings, likes, dislikes, and so on, about topics that caught their attention and situations in their immediate contexts. We took into account what we had identified about students likes and dislikes in order to add activities to the webpage. The participants faced reallife situations, and they had to choose between options.

The web page had a system to upload audios that the teacher could check frequently. It offered spaces in which students could identify speaking errors that were checked by the teacher through the audio. Based on the recordings, we had the opportunity to listen and correct pronunciation in order to help students improve their accuracy and fluency when speaking.

At the end of each activity, a box appeared where students had to write what they had learnt. In addition, they could reflect about the role he or she had played. Students could also suggest activities that they wanted us to include on the webpage. This allowed us to find appropriate activities and include students' interests. The webpage included workshops designed using a program called Flash. Each workshop had three activities and one recognition stage in order for students to listen and connect the audio, words, and pictures for meaningful learning. Vega (2016) said that oral comprehension can be encouraged by using ICTs because of the great quantity of audio material that can help students understand the language and use it in different situations. In that sense and in order to achieve the main goal of the study, we concluded that the webpage could offer different kinds of activities based on listening about issues and other topics of interest.

To plan the workshops, we implemented the "Matriz para la planeación y desarrollo de actividades proyecto de intervención pedagógica" designed by a professor from the Universidad 
Pedagógica y Tecnológica de Colombia. Each workshop followed a format with a title, date, place, time, aim, participants, resources, procedure, theoretical bases, evidences, and the evaluation of the activities' results. This last section was divided into achievements, difficulties, and questions about the activity.

Bearing in mind the topics assigned to the students, the workshops were titled: Let me introduce myself, This is my classroom, Where are you from?, What do you do?, The Simpson's family, and Who has got...? In the procedure stage, students had to log into www.enhancingenglish.com, which was the webpage address where they could find the activities related to the main topic. For example, in the first workshop called Let me introduce myself, the students followed the procedure shown in the following table:

Table 1

Procedure followed in workshop 1 taken from the matrix



In the Simpson's Family workshop, students found the presentation of the topic, and they had to listen to what each member of the family was wearing. With this workshop, students were working with vocabulary about clothes, possessive adjectives, colors, and family members. 


\section{Findings}

Based on the data and their analysis, the findings were classified in three categories. The main category was titled 'Using ICTs to catch students' attention and encourage them to use previous knowledge in English Language". This category was selected based on its relation to the students' speaking skill. We were able to see the way students practiced and learnt, how they progressed through the different stages, and the autonomous work they carried out from the very beginning of the workshops. Additionally, the main category was chosen based on the students' progress in developing their speaking skills when they used the webpage during their free time. To delve deeper into the main category, two subcategories emerged. The first dealt with the aspects that were improved when working on speaking skills. The second was related to the students' commitment, perseverance, and self-assessment, according to the progress they had with their own autonomous learning during the workshops. The title for the subcategories was "Connecting previous knowledge with real contexts to speak about topics related to my life" and "Listening to vocabulary to recognize and talk about real situations".

In the main category, "Using ICTs to catch students' attention and encourage them to use previous knowledge in English Language", the students affirmed that they could understand the English language in a better way through the implementation of the webpage, which let them play and learn at the same time. Therefore, they felt motivated to develop the different activities presented in the workshops. Extracts that support this category are the following:

porque usamos el computador la tablet y ademas de eso abian juegos ay mismo y aprendo jugando y no escribiendo.

[because we use the computer and tablet. Also, I learn playing games instead of writing]. (Reflection, Student D)

por que era muy divertido y tambien havian juegos en Ingles por eso se me facilita más.

[because it was really fun, and there were games in English. That is why it is easier for me.] (Reflection, Student R)

It was evident that students had fun while they were developing the activities. Juan and García (2013) mentioned that learning a foreign language can be a demotivating process. That is why teachers should provide students with meaningful and real activities, and games can be a 
way to reach that goal. Wright (1984, as cited in Juan \& García, 2013) pointed out that the games offer participants a sense of self-confidence.

The students felt motivated because they were learning in a different and flexible way, connecting ideas, recognizing feelings and sounds, and playing with the interactive activities using technology. According to Madhavi (2010, as cited in Viatonu, 2012), the "communicative method for learning languages combines extensively, high-quality content with flexible and interactive multimedia technology, because of these learners can respond at ease for communicative mode of teaching" (p. 2). The students thought that the webpage was a fun way to learn, as mentioned by students $\mathrm{A}$ and $\mathrm{F}$ :

la pajina mostraba cosas divertidas y uno iva aprendiendo poco a poco.

[The page showed fun things that we would be learning little by little]. (Reflection, Student F)

es muy divertido aprender. [It is very fun to learn]. (Reflection, Student A)

The previous excerpts might be explained in Duta and Martínez's words (2015) “it (ICT) facilitates learning of content where the student becomes an active agent in the educational process itself" (p. 1471). Here, Student A emphasized what and how he could do the activities based on the webpage.

When students were developing the workshops on the webpage, they were involved in learning the English languages. The students were understanding the language, which they needed to do in order to follow the games and activity instructions. Their comprehension allowed them to develop the exercises and find other activities. Because they needed to understand the language to finish the workshop, they tried to comprehend the instructions based on what they had seen in the previous activities and recognition stages. Student T reflected the following:

porque la pagina lo distrae a uno mismo sino que uno tiene que estar concentrado.

[The page can be distracting, so one has to be focused]. (Reflection, Student T)

The students were motivated in different ways with graphics, sounds, characters, and so on. So, they had to be focused on what they had to accomplish and what they needed in order to

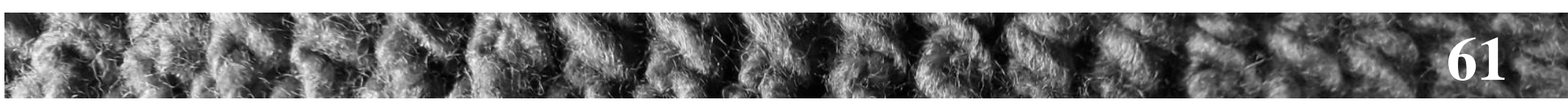


progress. In a study carried out by Duta and Martínez (2015), ICTs increased the participants' motivation, while allowing them a better understanding of learning objectives.

Vega (2016) asserted that the first and most important benefit for students when using ICTs is that their motivation increases in the learning teaching process, which could be higher than using traditional resources.

\section{First Subcategory: Connecting Previous Knowledge with Real Contexts to Speak About Topics Related to my Life}

According to the collected data and analysis, we noticed that the webpage helped students connect to their realities with vocabulary and spaces to use it. Students D, K, and J shared the following reflections:

antes no sabia lo que ahora, la pagina me ayuda a entender las cosas que tengo alrededor de mi.

[Before I didn't know, but the webpage allowed me to understand the things around me]. (Reflection, Student D)

podemos avanzar aprendiendo inglés con la pagina y nos ayuda en nuestras vidas cotidianas.

[We can advance in learning English with the webpage, and it helps us with our everyday lives].

(Reflection, Student K)

los personajes son animados y uno se puede acordar gracia a el.

[The characters are animated, and one can remember thanks to that]. (Reflection, Student J)

Agra, Formiga, Oliveira, Costa, Fernándes, and Nóbrega (2019) referred to learning as a process that is continuous, personal, and intentional. The last fact holds up when Student $\mathbf{J}$ was able to remember the characters given their animated features. Agra et al. said that "...intentional [process] is up to the student to relate substantively the new information with the relevant ideas existing in their cognitive structure" (p. 249). When students are able to relate knowledge with content, they are able to have meaningful learning. This is evident in their reflections since the participants noticed the relationship between their contexts and the situations presented on the webpage. 
Me parecio muy chebre la pagina te ayuda a aprender un poco mas del idioma del inglés ya que te ayuda a reforsar lo que aprendes en el colegio y si quisieras podrías utilizar la página durante muchos años.

[I thought it was really cool how the webpage helped me learn a bit more about English since it reinforces what we learn in school. If you wanted to, you could use the webpage for many years]. (Reflection, Student B)

es como un refuerzo para los talleres desarrollados en clase y por que uno puede jugar.

[It is like a reinforcement for the workshops we completed in class, and we can also play]. (Reflection, Student B)

me gustó mucho las actividades y al explicar las cosas es muy buena la pagina nos enseña mucho y ademas es un refuerzo.

[I really liked the activities and the explanation is really good on the webpage. It teaches us a lot and it is a reinforcement]. (Reflection, Student E)

\section{Second Subcategory: Listening to Vocabulary to Recognize and Talk about Real Situations}

Through the recordings and reflections, we noticed that the participants needed to increase their vocabulary knowledge in relations to the situations they were involved in daily. The students also needed an environment where they did not feel stressed to pronounce sentences or words incorrectly. After reviewing the literature about incidental vocabulary, Restrepo (2015) discussed the importance of quality contextual hints that allow subconscious acquisition of vocabulary.

At the end of each workshop, students recorded situations and described environments and characters by using the topics and vocabulary learnt and trying to perform like the characters.

antes no pronunciaba bien pero fui aprendiendo de a poco.

[Before, I did not pronounce well, but I learned little by little]. (Reflection, Student C) 
las actividades hacen más simple entender la pronunciación de todo.

[The activities make it easier to understand all of the pronunciation]. (Reflection, Student J)

la pronunciación es muy bonita porque desde que uno la entienda más fácil va a ser

[Pronunciation is great as long as you can understand it, it will be easier]. (Reflection, Student V)

In order to create a communicative environment, students listened carefully to the vocabulary connecting it with the representative image and space. Burkart (1998) mentioned that Mechanics consists of the correct use of words, sentences, and pronunciation. In fact, Mechanics is related to grammar language knowledge. Based on these aspects, we confirmed that the students tried to connect all of the aforementioned with a special emphasis on functional statements. Functional statements refer to speaking about things they did or surrounded them. The following excerpts are examples of the students' speaking skill:

There are apples in the books. there are flags at the top of the hotel. there are two students absent today. there is a car on the road. there is an iPad in my bag. There is a lamp in my bedroom. we have got two red bicycles.” (Audio, Student S)

Phonetic transcription:

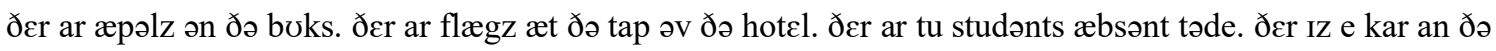
rod. ðعr IZ æn ay- pad ən may bæg. ðعr Iz e læmp ən may bedrum. wi hæv gat tu red bisıkəlz” (Audio, Student S)

In fact, the same student affirmed, in the reflection, that vocabulary and pronunciation had improved: “antes no pronunciaba bien y ahora si lo hago [Before, I did not pronounce well, and now I can]. The following transcription is the first record from Student T:

The first activity was a m..? there I found some objects and I had to say what was the objects the four activity was a listening exercises and finally the last activity that I did was an exercise which name was what are you got.. was the name was." (Audio, Student T)

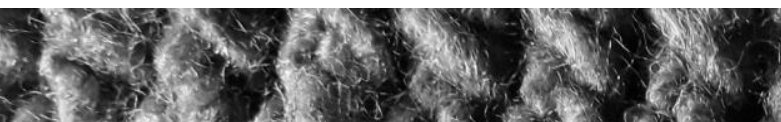


Phonetic transcription:

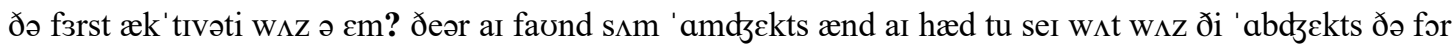

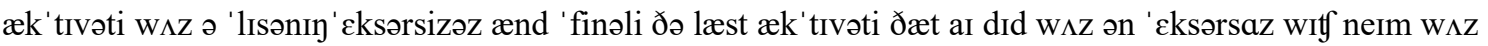

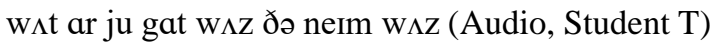

The following transcription is the second one from Student T:

My name is ... my grade is sixty two _this is my report about the five activity that I did, the first-first activity was about a puzzle where I had to use some cards from a box with there is and there are, in the second activity I had to find fifteen differences between who image and also I had today how many objects there was or there were. (Audio, Student T)

Phonetic transcription:

may nem IZ ... may gred IZ sıksti tu _ ðIs IZ may ripərt əbawt ðə fayv æktıvəti ðæt ay dıd, ðə fərst- fərst

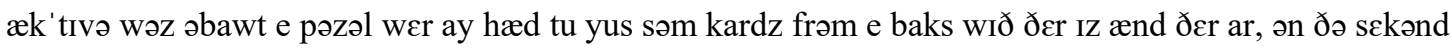
æktıvəti ay hæd tu faynd fif' tin difərənsəz bətwin hu Iməj ænd olso ay hæd təde haw meni amdzekts ठعr wəz or ðعr wər. (Audio, Student T)

Based on the previous recordings, Student T reviewed mistakes and corrected them in order to improve pronunciation. As a result, she went from four mistakes in the shorter intervention to two mistakes in the longer one. The participant showed autonomous learning because the teacher suggested to Student T that she should review the pronunciation of words like object, fifteen, activity, and exercise. We noticed that Student T pronounced these words correctly, even when she used them in a different activity.

As it was mentioned previously, Vega (2016) referred to some of the benefits students have using ICTs in learning a foreign language. She said that vocabulary and grammar structures acquisition can be reinforced and improved. In addition, she stated that the activities could be completed at home.

Another relevant aspect was the participants' autonomy showed in the development of the workshops. The students could reinforce the topics presented in class as independent work, especially when they could not access the webpage due to an unstable internet connection. Jiménez et al. (2007) assert that autonomous learning is the ability that any person has to develop

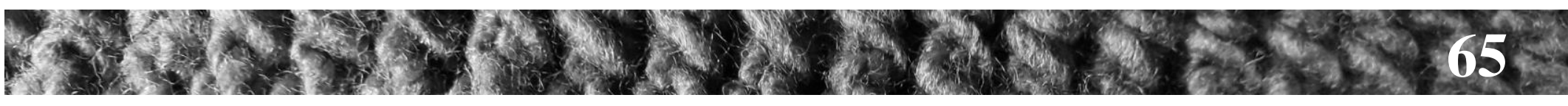


in a self-determined, social, responsible, and critical way in order to get personal empowerment and social transformation. Participants wanted to keep playing, so they developed the workshops at home. In order to foster autonomous learning, students had to be motivated, which was evident among the participants. In the same way, Duta and Martínez (2015) expressed that “...technology has meant the opportunity to generate many learning spaces which are not always managed or controlled by a figure such as the teacher" (p. 1467). It means that it was not necessary to have the teacher's presence in order to get responsibility and motivation from the students. This statement can be supported in Student O's reflection:

me gusta entrar a mirar que más tiene. Quiero aprender más inglés.

[I like to go in the webpage and check what else is there. I want to learn more English]. (Reflection, Student O)

Students asserted that they checked the page all the time in order to play in another workshop, whereby they had fun and learned. They also reinforced the topics the teacher had presented to them before. One of the participants shared the following:

Me gustaría entrar a la pagina en mi tiempo libre porque es chebre y aprenderia mas.

[I would like to enter the webpage during my free time because it is fun and I learn more]. (Survey, Student $\mathrm{O})$.

Dickinson (1987) said that an autonomous learner can work on accepting their own decision over their process. This work can be done without the direct control of the teacher or access to the material. The students were completely free to log into the webpage and work when they wanted and on whatever they wanted or needed to do.

At the same time, it is important to highlight the different perspectives that students demonstrated from the first questionnaire applied. At the beginning, all the participants considered the internet and new technologies as a means to listen to music, play games, chat in social networks, and watch videos and pictures. After the implementation of the webpage and second questionnaire, we found that the participants realized they could play and learn at the same time. In that sense, thew new perspective changed their vision on the uses of ICTs and the internet. 
me enseño más de lo que sabía antes de entrar a la página.

[It taught me more than what I knew before entering the webpage]. (Reflection, Student T)

Es bueno que en los juegos hablan en "english para todo".

[It is good that the games use "English for Everything"]. (Reflection, Student L)

Finally, we identified that the activities had an appropriate and consecutive order of topics, which let the students follow a process to have the tools to speak about a known topic. The previous idea is supported by Brown (1994), who explained that the speaking ability is an interactive process that involves construction, production, and process of information. The students could interact with the language through different exercises, which let them practice and remember how to use the language. After analyzing the template, we used on positive and negative events during the workshops, we conclude that the activities were carried our in an appropriate order that allowed the students to improve their speaking skills in the foreign language.

\section{Conclusions}

Bearing in mind the research question, "What does the implementation of a webpage reveal in the improvement of student's speaking skills?" and data, we can conclude that the following aspects were revealed after the implementation of a webpage with a group of sixth graders in a public institution in Tunja.

The use of ICTs in the English classes helped catch the students' attention and encourage them to speak in English. The participants argued that playing was linked to learning, and both aspects were present on the webpage. For the students, motivation was a fundamental issue during the workshops and a key element to learning English.

Secondly, the students highlighted the importance of linking English language learning and real situations. Some of the students expressed the previous in their reflections. Authors like Juan and Garcia (2013) theoretically supported the association of having fun while learning. 
This study revealed that the implementation of ICTs promotes the use of previous knowledge students have in English. The participants called attention to the motivation provided by the webpage and the necessity to apply their previous English knowledge in order to play the games and reach the goal.

Another fact that the implementation of the web page revealed was that participants noticed the relationship between their contexts and the situations presented on the webpage. The students focused on the way the webpage contributed to learning English, as well as the reinforcement of topics studied in school. Some of the students mentioned that the workshops could be seen as reinforcement activities.

The work on autonomous learning was another facet revealed by implementing the webpage. Despite the issues we faced with the internet, the students still looked for opportunities to work on the webpage during their free time and at home.

Taking into account that improving the speaking ability was the goal of this study, the use of the webpage revealed that it was a chance for students to listen and talk about real situations. We identified through the recordings and reflections that the participants needed to increase their vocabulary in order to participate. The implementation of the webpage was an opportunity for students to create an environment without feeling stressed to pronounce sentences or words incorrectly. 


\section{About the Authors:}

llba Yaneth Rodríguez Tamayo holds a B.A. in Education with an emphasis in English and Spanish and a M.A. in Applied Linguistics to English Teaching from the Universidad Pedagógica y Tecnológica de Colombia (UPTC) and the Universidad Distrital Francisco José de Caldas. She is a professor in the Modern Languages Program and the M.A. in Language Teaching at the UPTC. Additionally, she is the Secretary of the Academic Board at the same university. She is a member of Ambientes Virtuales Educativos Research Group.

Yelipsa del Pilar Barrera Parra is a teacher and alumni of the Universidad Peadgógica y Tecnológica de Colombia. She graduated in 2011 with a B.A. in Modern Languages with an emphasis in Spanish and English. Additionally, she he has experience in the private and public sectors of education, as well as in teaching basic, intermediate, and advanced English levels. She is currently studying a specialization and master's in Information and Communication Technology for Teaching with the objective of widening the cognitive field and offering innovative tools that help the teaching and learning process.

Amanda Lizeth Burgos Jiménez has a B.A. in Modern Languages with an emphasis in Spanish and English and Teaching English as a Foreign Language. She is known as a committed, responsible, innovative, creative, and dynamic teacher in her field. Amanda is well-versed in Information and Communication Technologies in oral and written form. Additionally, she has experience in teaching English at different institutions and educational levels, especially in the private sector like at Colegio la Presentación in Tunja, Colombia and Liceo Psicopedagógico Jean Piaget.

Adriana Lizeth Cuevas Peña holds a B.A. in Modern Languages and a specialization in Linguistics from the Universidad Pedagógica y Tecnológica de Colombia. She is a college professor at the same university. 
Andrea Nataly Lara Vargas holds a B.A. in Modern Languages with an emphasis in Spanish and English. She has a specialization in Educational Management, as well as professional development skills in teaching Spanish and English. She is a responsible, honest, and proactive teacher, as well as being a team worker and leader in her field. She has worked as an English teacher at the Universidad Pedagógica y Tecnológica de Colombia in its Chinquinquirá campus, Academica Shakespeare, and Colegio Nuestra Señora de Nazareth

\section{References}

Agra, G., Formiga, N. S., Oliveira, P. S., Costa, M. M. L., Fernandes, M. G. M., Nóbrega, M. M. L. (2019). Analysis of the concept of meaningful learning in light of the Ausubel's Theory. Rev Bras Enferm, 72(1), 248-255. http://dx.doi.org/10.1590/0034-7167-2017$\underline{0691}$

Bachman, L. F. (1990). Fundamental considerations in language testing. Oxford University Press.

Brown, D. (1994). Interactive language teaching in initial interaction in: Principles of language learning and teaching ( $3^{\text {rd }}$ ed.). San Francisco state University.

Bruce, B. C., \& Levin, J. A. (1997). Educational technology: Media for inquiry, communication, construction, and expression. Journal of Educational Computing Research, 17(1), 79102.

Burkart, S. (1998). Spoken language what is it and how to teach it. Center for Applied Linguistics. Washington, DC.

Burns, A. (2015). The Cambridge guide to research in language teaching and learning ( $\left.1^{\text {st }} \mathrm{ed}.\right)$. Cambridge University Press.

Christensson, P. (2006) Web Page definition. http://techterms.com

Dickinson, L. (1987). Self-instruction in language learning. Cambridge University Press.

Duta, N., \& Martínez-Rivera, O. (2015). Between theory and practice: The importance of ICT in higher education as a tool for collaborative learning. Procedia - Social and Behavioural Sciences, 180, 1466-1473.

https://www.researchgate.net/publication/277947422_Between_Theory_and_Practice_Th e_Importance_of_ICT_in_Higher_Education_as_a_Tool_for_Collaborative_Learning 
Espuny, C., Gisbert, M., \& Coiduras, J. (2010). La dinamización de las TIC en las escuelas. Edutec. Revista Electrónica De Tecnología Educativa, (32), 131. https://doi.org/10.21556/edutec.2010.32.436

Gnambs. T. \& Hanfstingl, B. (2016) The decline of academic motivation during adolescence: An accelerated longitudinal cohort analysis on the effect of psychological need satisfaction. Educational Psychology, 36(9), 1691-1705. https://doiorg/10.1080/01443410.2015.1113236

Heigham, J., \& Croker, R. (Eds.) (2009). Research in applied linguistics: A practical introduction. Palgrave MacMillan.

Hopkins, D. (2002). A teacher's guide to classroom research ( $3^{\text {rd }}$ ed.). Open University Press.

Hung, E. (Ed.). (2015). Hacia el fomento de las TIC en el sector educativo en Colombia. Universidad del Norte.

Hymes, D. H. (1972). On communicative competence. In J. B. Pride \& J. Holmes (Eds.), Sociolinguistics, (pp. 269-293). Penguin Education, Penguin Books Ltd.

Jiménez Raya, M., Lamb, T., \& Vieira, F. (2007). Pedagogy for autonomy in language education in Europe: Towards a framework for learner and teacher development. Authenti.

Juan, A., \& García, I. (2013). El uso de juegos en la enseñanza del inglés en la educación primaria. Revista de Formación e Innovación Educativa Universitaria, 6(3), 169-185.

Ministerio de Educación. (2009). Ley 1341 de 2009. https://www.mintic.gov.co/portal/604/articles-3707_documento.pdf

Molina-Pacheco, L., \& Mesa-Jiménez, F. (2018). Las TIC en escuelas rurales: Realidades y proyección para la integración. Praxis \& Saber, 9(21), 75-98. https://doi.org/10.19053/22160159.v9.n21.2018.8924

Restrepo Ramos, F. D. (2015). Incidental vocabulary learning in second language acquisition: A literature review. PROFILE Issues in Teachers' Professional Development, 17(1), 157166. https://doi.org/10.15446/profile.v17n1.43957.

Rico Yate, J. P., Ramírez Montoya, M. S., \& Montiel Bautista, S. (2016). Desarrollo de la competencia oral del inglés mediante recursos educativos abiertos. Apertura, 8(1)1-15. https://www.redalyc.org/articulo.oa?id=688/68845366006 
Salazar Obeso, W. (2015). Exploring communicative competence development in an EFLT classroom at Cursos Libres. Zona Próxima, (23), 88-

103. https://dx.doi.org/10.14482/zp.22.5832

Vega, B. (2016). Uso de las Tic en el aula de lenguas extranjeras en educación primaria. [Master's thesis, Universidad de Cantabria].

Viatonu, O., \& Kayode, T. (2012). Improving the teaching and learning of English language through the use of information and communication technology: Prospects and challenges. https://conference.pixelonline.net/conferences/ICT4LL2012/common/download/Paper_pdf/38-IBT104-FPViatonu-ICT2012.pdf 


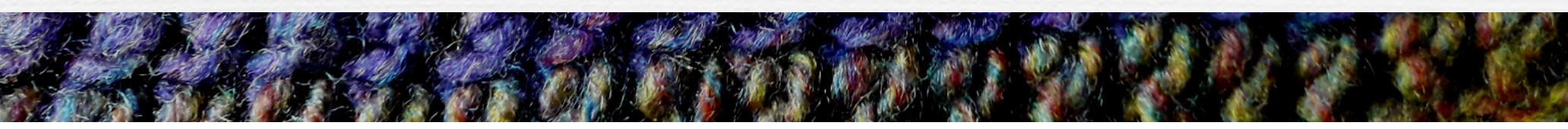

\section{ANNEX 1: Workshop 4}

\begin{tabular}{|c|c|c|c|c|c|c|}
\hline No. & WORKSHOP NAME & DATE & PLACE & TIME & AIM & PARTICIPANTS \\
\hline 4 & What do you do? & & $\begin{array}{l}\text { Virtual } \\
\text { Classroom }\end{array}$ & $\begin{array}{l}\text { Two } \\
\text { hours } \\
\text { (120 } \\
\text { minutes) }\end{array}$ & $\begin{array}{l}\text { 1. To use the knowledge students } \\
\text { have got about topics related to } \\
\text { them, as jobs and professions. } \\
\text { 2. To improve the students } \\
\text { pronunciation and vocabulary } \\
\text { through contextualized activities } \\
\text { 3. To collect the students audio } \\
\text { recordings. } \\
4 \text {. To make students reflect about } \\
\text { their own performance }\end{array}$ & $\begin{array}{l}\text { Sixth graders of the } \\
\text { Institution }\end{array}$ \\
\hline & RESOURCES & \multicolumn{2}{|c|}{ PROCEDURE } & \multicolumn{2}{|c|}{ THEORETICAL BASES } & EVIDENCES \\
\hline \multicolumn{2}{|c|}{$\begin{array}{l}\text { Tablets } \\
\text { Internet } \\
\text { Notebooks }\end{array}$} & \multicolumn{2}{|c|}{$\begin{array}{l}\text { 1. Teacher make students } \\
\text { remember their tasks } \\
\text { 2. Students log in to the web } \\
\text { page } \\
\text { www.enhancingenglish.com } \\
\text { 3. On the web page, students } \\
\text { see the presentation of the } \\
\text { topic, here there are } 14 \\
\text { images, each one with its } \\
\text { corresponding audio. } \\
\text { 4. Then students find fourteen } \\
\text { sceneries, there they can find } \\
\text { various elements related to } \\
\text { the job or profession. }\end{array}$} & \multicolumn{2}{|c|}{$\begin{array}{l}\text { Learning strategies; Oxford (1991) "Language } \\
\text { learning styles and strategles are among the } \\
\text { main factors that help determine how -and } \\
\text { how well -our students learn a second or } \\
\text { foreign language" } \\
\text { Autonomous learning: Leslie Dickinson (1987) } \\
\text { an autonomous learner can work on: accept } \\
\text { their own decision over their process, work } \\
\text { without the direction or control of teacher and } \\
\text { access to material } \\
\text { Web pages as strategy for teaching. } \\
\text { According to Viatony, } 2012 \text { "communicative } \\
\text { method for learning languages combines } \\
\text { extensively, high-quality content with flexible } \\
\text { and interactive multimedia technology, }\end{array}$} & $\begin{array}{l}\text { Audio recordings } \\
\text { Reflections } \\
\text { Students notebooks }\end{array}$ \\
\hline
\end{tabular}

